\title{
Analyzing Verbal Idioms in Gadis Pantai Novel of Pramoedya Ananta Toer
}

\author{
Muhammad Zainul Arifin, Suyitno, Raheni Suhita
}

Master of Indonesian Language Education, Sebelas Maret University, Surakarta, Indonesia

Received: 16 Nov 2020; Received in revised form: 3 Dec 2020; Accepted: 6 Dec 2020; Available online: 14 Dec 2020

(C)2020 The Author(s). Published by Infogain Publication. This is an open access article under the CC BY license

(https://creativecommons.org/licenses/by/4.0/).

\begin{abstract}
The research aimed to analyze the verbal idioms by using semantic analysis. It is a descriptive qualitative design that applied text analysis focusing on one phenomenon. The data collection taken are words that contain idiomatic meanings in the novel of Gadis Pantai by Pramoedya Ananta Toer. The writer collected the data through observation and note-taking techniques. The writer administered source triangulation and theoretical triangulation to test the validity. The result shows that there are five idioms which are formed by using verbs. There are eleven idioms created using transitive affixed verbs, which consisted of 8 phrasal verb idioms and eight partial idioms. There is a finding that nouns always follow the constituent elements of idioms to obtain the idiom's meaning.
\end{abstract}

Keywords-idioms, meaning, novel, verbs.

\section{INTRODUCTION}

According to (Akbar, 2013:58) a novel is a fictional story that elevates human life consisting of intrinsic and extrinsic elements to explain the author's events. The life depicted in writing is dramatized to lead the reader to follow the storyline. The story in the novel reflects the reality in which the author expresses his feelings based on society's culture.

Generally, the novel's contents can be in the form of problems arise because of differences or conflicts in some situations to achieve a goal. The author conveys the message and value of life through literary works. Readers are expected to interpret, collect the author's message, and understand how the message and the whole parts interact coherently (Telgen, D., Hile, 1998:vii).

The readers will be more attracted to the novels containing aesthetic values. Authors can express their thoughts and feelings in a literary work. The description of events and flows that occurred is carried out in detail. Novels often bring up conflicts from different circumstances. Novels can influence other's perceptions of thoughts about society in life (Parrinder, 2006:9).

The Novel of Gadis Pantai by Pramoedya Ananta Toer can be classified as a historical novel that tells about events according to facts. Moreover, it is presented by the author's imagination. The choice of words in the novel is an important element. Each text has different linguistic elements, for example, in a historical novel. Every novelist must have his characteristics in his work, such as language rules, including idiomatic meaning. There is a difference between spontaneous expression and written messages. Written media allows authors to reflect, modify, and improve before publication (Jackson, 2013:244).

Mastering idioms in discourse is an important aspect of improving vocabulary lists, communicative skills, conversations, and written texts. Rijal, (2018) has researched Indonesian idioms found in the field of rural culture. The research is a combination of science between anthropology and linguistics. In general, learning idiomatic language components can lead to an increase in language abilities and skills.

Based on the background, the researcher wanted to analyze the types and the idiomatic meanings in the novel of Gadis Pantai by Pramoedya Ananta Toer, whose constituent elements are verbs. The purpose of this research is to describe the types and meanings based on verbal idioms. The benefits of this research are expected to increase knowledge about idioms. 


\section{LITERATURE REVIEW}

Gairns (2011:5) defined idiom as a sequence of words that are different from the individual word. Thus some idioms' meaning is difficult to understand outside the context. The idiom can be seen if there's incapability between contextual situations of phrase relevant with the sentence.

Meanwhile, according to (McCarthy M. and O'Dell, 2017:6) idiom is an expression whose meaning is often difficult to guess from each word's meaning. The easiest way to understand the idiom is by seeing the context of language itself. So, it can be concluded that an idiom is a unit of words arranged in a certain order, which the meaning of it cannot be guessed from the composition of words.

Idioms are different from the regular vocabulary. They implicitly mean that language is constructed compositionally. For example, the grammatical and lexical elements express their meaning and relationship from one to another. There is a difference between the meaning of the phrase and the meaning of the constituents on its composition (Philip, 2011:15).

The idiom types would be determined based on the theory of Idioms proposed by Palmer, (1976:98-99). Then the analysis of English idioms is found also includes the analysis of the meaning. He stated that the idioms are classified into two types. The first is phrasal verb idiom, which means all the words can have one different meaning from its linguistic meaning. Second, a partial idiom is an idiom in which one of the words has its lexical meaning; the other has a meaning peculiar to the particular sequence. Fernando, (1994:36) proposed three types of idiomatic expressions: pure, semi, and literal idioms. Pure idioms are formed from multiword, which meaning is different from the previous one. Semi-idioms mean that partial words have their meaning, the other does not. The last is literal idioms with a literal form of idioms that can have the same meaning as its basic meaning.

According to Baryadi, (2013:50), verbs used as elements to form idioms can be divided into an ordinary verb and derivative verb. Ordinary verbs are verbs that have not undergone a morphological process. Derivative verbs have undergone a morphological process, such as addition, repetition, and compounding.
It is important to emphasize that the idiom's composition does not determine the condition of truth, but it is based on context. The condition of truth is the only criterion established to give meaning to idioms as the phrase's product in a situational environment or textual context. Idioms can be analyzed when a mismatch between the situation's context or the relevance of a phrase in a sentence.

\section{METHOD}

The setting of this study is flexible. The research used is descriptive qualitative design. It applied text analysis, which focused on one phenomenon. The data collection taken are words that contain idiomatic meanings in the novel of Gadis Pantai by Pramoedya Ananta Toer. The writer collected the data through observation and notetaking techniques. The writer administered source and theoretical triangulation. The data analysis used is a model from Miles, B.M.,\& Huberman (1992:17-20). These steps are data collection, data reduction, data display, and drawing conclusions.

\section{FINDING AND DISCUSSION}

Palmer, (1976:98-99) divided two types of idioms: phrasal verb idiom and partial idiom. The first is phrasal verb idiom, which means all the words can have one different meaning from its lexical meaning. Second, a partial idiom is an idiom in which one of the words has its lexical meaning; the other has a meaning peculiar to the particular sequence.

\subsection{The Ordinary Verb as the Constituent of Idioms}

Ordinary verbs are independent verbs, namely verbs that can already be used in a sentence without having a morphological process. Basic verbs combined with the words that follow can form idioms, as follows:

Table 1 The Data on Ordinary Verbs

\begin{tabular}{|c|l|l|l|l|c|}
\hline No & \multicolumn{1}{|c|}{ Ordinary Verb } & \multicolumn{1}{|c|}{ Idiomatic Data } & \multicolumn{2}{|c|}{ Meaning } & \multicolumn{2}{|c|}{ Idiom } \\
\cline { 5 - 6 } & & & & Phrasal verb & Partial \\
\hline 1 & Mandi & mandi matahari \\
& Take a bath & Barmed bathe & Sunbathe & & \\
\end{tabular}




\begin{tabular}{|c|l|l|l|c|c|}
\hline 2 & $\begin{array}{l}\text { Banting } \\
\text { Slam }\end{array}$ & $\begin{array}{l}\text { banting tulang } \\
\text { Work to the bone }\end{array}$ & $\begin{array}{l}\text { kerja sungguh-sungguh } \\
\text { Work hard }\end{array}$ & V & \\
\hline 3 & $\begin{array}{l}\text { Mandi } \\
\text { Take a bath }\end{array}$ & $\begin{array}{l}\text { mandi keringat } \\
\text { Bathe in our sweat }\end{array}$ & $\begin{array}{l}\text { kerja keras } \\
\text { Work hard }\end{array}$ & $\mathrm{V}$ & \\
\hline 4 & $\begin{array}{l}\text { Peras } \\
\text { Squeeze }\end{array}$ & peras keringat & $\begin{array}{l}\text { kerja keras } \\
\text { Work hard }\end{array}$ & $\mathrm{V}$ & \\
\hline 5 & $\begin{array}{l}\text { Buka } \\
\text { Open }\end{array}$ & $\begin{array}{l}\text { Muka mulut } \\
\text { open your mouth }\end{array}$ & Talking about a secret & & $\mathrm{V}$ \\
\hline
\end{tabular}

The idioms are formed by using the ordinary word without the need for the affixation process. The phrase "mandi matahari" (Toer, 2000:173) does not have a true meaning. The word "mandi" means cleaning the body using water and soap, whereas "matahari" means celestial body, the center of the universe. Based on the combined words, it means sunbathing.

The data of "Your father and I had to work ourselves to the bone so that you could have batik" (Toer, 2000:13) denotatively means "banting" or throw something hard, whereas "tulang" means a part of the human or animal body. If that expression is translated denotatively, it will be difficult to be understood. So, it is translated into "bekerja keras," which means work hard.

The expression "bathe in the sea or even in our sweat" (Toer, 2000:144) means work hard. If that expression is translated denotatively, it will be difficult to be understood. So, it is translated into "bekerja keras" which means work hard. Moreover, it is the kind of phrasal verb idiom because it does not have a lexical meaning. The phrases formed using sensory responses.
The context of the sentence means that the energy expended produces a lot of sweat. However, working hard is not always synonymous with sweating. It can also work hard to be a person who has a good image.

According to the expression of "All you have to do is open your mouth" (Toer, 2000:113), the word open means opening something, and the word mouth lexically means the cavity which houses the teeth and tongue, or for feeding food. This phrase does not mean just opening your mouth to enter food, but talking to convey a secret to the general public should not be allowed. The above phrase can be categorized as a partial idiom because the word open still has its lexical meaning.

\subsection{The Derivative Verb as the Constituent of Idioms}

Derivative verbs used to form idioms include verbs affixed with me (N) -, ber-, ter-, di-, and verbs with affix ke-an. In Gadis Pantai novel, the derivative verbs are found as follows:

Table 2 The Data of Derivative Verbs

\begin{tabular}{|c|c|c|c|c|c|}
\hline \multirow[t]{2}{*}{ No } & \multirow[t]{2}{*}{ Derivative Verb } & \multirow[t]{2}{*}{ Idiomatic Data } & \multirow[t]{2}{*}{ Meaning } & \multicolumn{2}{|c|}{ Idiom } \\
\hline & & & & $\begin{array}{c}\text { Phrasal } \\
\text { Verb }\end{array}$ & Partial \\
\hline 1 & $\begin{array}{l}\text { Membuang } \\
\text { Abandon }\end{array}$ & $\begin{array}{l}\text { Membuang muka } \\
\text { Look away }\end{array}$ & $\begin{array}{l}\text { Tidak sudi } \\
\text { Avoiding }\end{array}$ & & $\mathrm{V}$ \\
\hline 2 & $\begin{array}{l}\text { Mendaki } \\
\text { Climb }\end{array}$ & $\begin{array}{l}\text { Mendaki lantai } \\
\text { Climbed a set of stairs to the } \\
\text { raised ground floor }\end{array}$ & $\begin{array}{l}\text { Berjalan di ruangan pembesar } \\
\text { Walking on a magnify-ing room }\end{array}$ & & $\mathrm{V}$ \\
\hline 3 & $\begin{array}{l}\text { Menjual } \\
\text { Sell }\end{array}$ & $\begin{array}{l}\text { Menjual omong } \\
\text { Sell fairy tale }\end{array}$ & $\begin{array}{l}\text { Banyak bicara } \\
\text { Talking too much }\end{array}$ & & $\mathrm{V}$ \\
\hline 4 & $\begin{array}{l}\text { Menggaruki } \\
\text { Scratch }\end{array}$ & $\begin{array}{l}\text { menggaruki genteng } \\
\text { Shake the roof tiles }\end{array}$ & $\begin{array}{l}\text { Menerpa kencang atap } \\
\text { Hit the roof }\end{array}$ & & $\mathrm{V}$ \\
\hline
\end{tabular}




\begin{tabular}{|c|c|c|c|c|c|}
\hline 5 & $\begin{array}{l}\text { Merenungi } \\
\text { Contempla-te }\end{array}$ & $\begin{array}{l}\text { merenungi lantai } \\
\text { Lowered eyes toward the } \\
\text { floor }\end{array}$ & $\begin{array}{l}\text { Diam hormat } \\
\text { To be respectfully silent }\end{array}$ & $\mathrm{V}$ & \\
\hline 6 & $\begin{array}{l}\text { Mengaduk } \\
\text { Stir }\end{array}$ & $\begin{array}{l}\text { mengaduk laut } \\
\text { Face the sea }\end{array}$ & $\begin{array}{l}\text { Menyelam } \\
\text { Dive }\end{array}$ & & $\mathrm{V}$ \\
\hline 7 & $\begin{array}{l}\text { Menggaruk } \\
\text { Scratch }\end{array}$ & $\begin{array}{l}\text { menggaruk pasir } \\
\text { Boring into the sandy }\end{array}$ & $\begin{array}{l}\text { Menatap ke bawah } \\
\text { Staring downside }\end{array}$ & $\mathrm{V}$ & \\
\hline 8 & $\begin{array}{l}\text { Menyulam } \\
\text { Embroider }\end{array}$ & $\begin{array}{l}\text { menyulam pantai } \\
\text { Ran up the strand }\end{array}$ & $\begin{array}{l}\text { Perbuatan sia-sia } \\
\text { Useless thing }\end{array}$ & $\mathrm{V}$ & \\
\hline 9 & $\begin{array}{l}\text { Membisu } \\
\text { Mute }\end{array}$ & $\begin{array}{l}\text { Membisu seribu bahasa } \\
\text { Completely tongue-tied }\end{array}$ & $\begin{array}{l}\text { Tidak ingin berkomuni-kasi } \\
\text { No communica-tion }\end{array}$ & & $\mathrm{V}$ \\
\hline 10 & $\begin{array}{l}\text { Mandi } \\
\text { Take a bath }\end{array}$ & $\begin{array}{l}\text { bermandi keringat dingin } \\
\text { Sweat shower }\end{array}$ & $\begin{array}{l}\text { Gugup } \\
\text { Feeling nervous }\end{array}$ & $\mathrm{V}$ & \\
\hline 11 & $\begin{array}{l}\text { Bermandi } \\
\text { Take a bath }\end{array}$ & $\begin{array}{l}\text { bermandi darah } \\
\text { Bloody shower }\end{array}$ & $\begin{array}{l}\text { Mengeluarkan banyak darah } \\
\text { A lot of bleeding }\end{array}$ & & $\mathrm{V}$ \\
\hline
\end{tabular}

The phrase sells by the way does not mean to buy or sell about the conversation. The word selling means giving something to someone else to get a payment or receive money. This phrase is part of an idiom, because the word talk still has a meaning that is similar to its lexical. The elements that make up the idiom come from the senses' responses. The meaning of this phrase arises when someone speaks to exaggerate something but it is different from what is said or better known as a lot of talks.

The word scratching can mean measuring, scratching the ground, scooping, scratching, and catching. The word scratching has a different meaning from the original meaning of the words, but the word tile still has its original meaning. So the phrase falls into the partial idiom category. The elements that make up the idiom come from the verb class. Idiomatically the phrase means to hit hard the roof of the house.

The word stirring is defined as mixing and disrupting, disrupting, dismantling chaotically. If analyzed using logic it cannot be accepted. The sea is so great that we cannot stir it up as stated above. The real meaning is to dive to the bottom of the sea. This phrase can be categorized as a partial idiom, because the word sea still fits the lexical. The constituent elements are related to the name of natural objects, namely the sea.

The word scratching means measuring the head, body, scratching the ground, or scraping. If examined in more detail how the view can scratch the sand. This shows that there are differences in the meaning used. The phrase can be categorized as a full idiom, because the meaning of the ISSN: 2456-7620 word does not match the lexical. The constituent elements are related to the name of natural objects, namely sand. The meaning of the idiom above is defined as looking down as respect for others.

The word embroider is defined as embroidering or praising. If the phrase is interpreted separately, it cannot produce an appropriate meaning. This phrase can be categorized as a full idiom, because the meaning of the words does not match the lexical meaning. The above phrase means useless actions. The constituent elements are related to the names of natural objects.

The word thousand is defined as the number, while language means the system of sound symbols used to communicate. The phrase muted by a thousand languages does not have so many languages in every language unit in this world. This expression can be understood as a person who does not want to communicate with those around him. Thus, the phrase is categorized as a partial idiom, because the word mute still has its lexical meaning. The constituent elements of idioms are related to verbs.

Based on the presence or absence of the objective function that follows it, verbs affix me $(\mathrm{N})$ can be divided into two types, which are transitive verbs with affix me (N)- and non-transitive verbs with affix me $(\mathrm{N})$-. The transitive verb affixing me $(\mathrm{N})$ demands an object's presence when used in a sentence.

In the data above, the words throw, climb, sell, scratch, contemplate, stir, scratch, embroider, and mute are transitive verbs that require an object. However, a 
transitive verb affixed of me $(\mathrm{N})$ - an element of the idiom does not necessarily have a balance of the passive sentence. The example is in the phrase, "Her mother turned her head away from the daughter to stare out the carriage window" (Toer, 2000: 14). The sentence does not have a passive sentence balance because the phrase cannot be accepted cohesion or coherence.

The verb affixed with ber- used as an element of forming an idiom needs to be distinguished from a verb attached to the idiom. In the example of "Her body was bathed in a cold sweat" (Toer: 2000: 31), the affix is not included in the idiom's constituent elements.

The data of the cold sweat (bermandikan keringat dingin) is an idiom of mandi keringat dingin attached to a prefix ber- and kan- which means nervousness. The same is the case with the data "I was covered in blood" (sahaya sudah bermandi darah) (Toer, 2000: 62), which comes from the idiom of bathing in blood (mandi darah), which means a lot of bleeding.

\section{CONCLUSION}

According to the explanation in the finding and discussion above, the writer can conclude that five idioms are formed by using verbs. There are eleven idioms formed using transitive affixed verbs, which consisted of 8 phrasal verb idioms and eight partial idioms. There is a finding that the constituent elements of idioms are always followed by nouns to obtain the idiom's meaning.

\section{REFERENCES}

[1] Akbar, S. (2013). Kajian Sosiologi Sastra dan Nilai Pendidikan dalam Novel "Tuan Guru” Karya Salman Faris. Jurnal Pendidikan Bahasa Dan Sastra, 1(1).

[2] Baryadi, I. P. (2013). Idiom Yang Berunsur Kata Kerja Dalam Bahasa Indonesia. Jurnal Ilmiah Kebudayaan SINTESIS, 7(1), 46-62.

[3] Fernando, C. (1994). Idioms and Idiomaticity. Oxford University Press.

[4] Gairns, R. \& R. S. (2011). Oxford Idioms Dictonary For Learnes of English 2nd. Oxford University Press.

[5] Jackson, H. (2013). Grammar and Meaning: a semantic a Coursebook. Routledge.

[6] McCarthy M. dan O'Dell, F. (2017). English Idioms In Use. Cambridge University Press.

[7] Miles, B.M., \& M. H. (1992). Analisis Data Kualitatif (Terjemahan). Universitas Indonesia.

[8] Palmer, F. R. (1976). Semantics: Second Edition. Cambridge University Press.

[9] Parrinder, P. (2006). Nation \& Novel The English Novel from its Origins to the Present Day. Oxford University Press.
[10] Philip, G. (2011). Colouring meaning: collocation and connotation in figurative language. John Benjamins Publishing Co.

[11] Rijal, S. (2018). Budaya Agraris Dalam Konsep Idiom Bahasa Indonesia: Kajian Antropolinguistik. Diglosia, 1(1), 45-52.

[12] Telgen, D., Hile, K. (1998). Novels for Students. Gale Research.

[13] Toer, P. A. (2000). Gadis Pantai. Hasta Mitra. 